Akreditasi KEMENRISTEKDIKTI, Nomor: 148/M/KPT/2020
http: / /jurnal.stkippersada.ac.id/jurnal/index.php/VOX

\title{
ANALISIS PENGARUH E-LEARNING MENGGUNAKAN SPADA TERHADAP EFEKTIVITAS BELAJAR MAHASISWA STMIK PRIMAKARA
}

\author{
Ni Komang Erikka Candra Pratiwi ${ }^{1}$, Ni Luh Putu Ning Septyarini Putri Astawa ${ }^{2}$, \& A.A. Istri Ita \\ Paramitha $^{3}$ \\ ${ }^{1,2,3}$ Program Studi Sistem Informasi, STMIK Primakara \\ Email:erikkacandra01@gmail.com ${ }^{1}$
}

INFO ARTIKEL
$\begin{aligned} & \text { Riwayat Artikel: } \\ & \text { Menerima }: 18 \text { Agustus } 2021 \\ & \text { Revisi } \quad: 23 \text { Agustus } 2021 \\ & \text { Diterima } \quad: 25 \text { Agustus } 2021\end{aligned}$

Kata Kunci:

e-learning, efektivitas belajar, metode campuran
Keywords:

e-learning, learning effectiveness, mixed methods

\section{Korespondensi:}

Ni Komang Erikka Candra

Pratiwi

Program Studi Sistem Informasi, STMIK Primakara

Email:

erikkacandra01@gmail.com

\begin{abstract}
ABSTRAK
Tujuan dari penelitian ini adalah untuk mengetahui tentang pengaruh $e$ learning menggunakan SPADA terhadap efektivitas belajar mahasiswa STMIK Primakara. Penelitian ini menggunakan metode mixed methods convergence model. Objek dari penelitian ini adalah 85 orang mahasiswa semester 2, 4, dan 6. Dalam penelitian ini, dilakukan identifikasi pengaruh $e$ learning menggunakan platform SPADA yang dikembangkan oleh STMIK Primakara berbasis Moodle terhadap efektivitas belajar mahasiswa. Peneliti menggunakan observasi, kuesioner tertutup, kuesioner terbuka, dan studi literatur sebagai teknik pengumpulan data. Empat indikator efektivitas pembelajaran yang digunakan dalam penelitian ini, yaitu quality of instruction, appropriate levels of instruction, incentive, dan time. Peneliti menggunakan analisis data kuantitatif dan analisis data kualitatif. Analisis data kuantitatif menggunakan skala Likert untuk menghitung data dari kuesioner tertutup sedangkan analisis data kualitatif menggunakan data dari kuesioner terbuka. Dalam penelitian ini ditemukan bahwa persentase persetujuan dengan indikator quality of instruction menunjukkan hasil 86,35\% (sangat efektif). Selanjutnya indikator appropriate levels of instruction dengan hasil 87,82\% (sangat efektif). Indikator ketiga, incentive dengan hasil perolehan 88,94\% (sangat efektif). Terakhir indikator time dengan hasil persentase persetujuan $89,56 \%$ (sangat efektif). Selain itu data kualitatif yang diperoleh juga menunjukkan bahwa penggunaan SPADA dapat mendukung proses belajar mahasiswa.
\end{abstract}

\section{ABSTRACT}

The purpose of this study was to determine the effect of e-learning using SPADA on the learning effectiveness of STMIK Primakara college students. This research uses a mixed methods convergence model. The object of this research is 85 college students in semester 2, 4, and 6. In this study, the identification of the effect of was conducted to identify the e-learning using the platform SPADA developed by STMIK Primakara based on Moodle was conducted to identify the effectiveness of college student learning. Researchers used observation, closed questionnaires, open questionnaires, and literature studies as data collection techniques. Four indicators of learning effectiveness are used in this study, namely quality of instruction, appropriate levels of instruction, incentive, and time. Researchers used quantitative data analysis and qualitative data analysis. Quantitative data analysis used a Likert scale to calculate data from a closed questionnaire, while qualitative data analysis used data from an open questionnaire. In this study, it was found that the percentage of approval with the indicator quality of instruction showed the result of $86.35 \%$ (very effective). Next is the indicator for appropriate levels of instruction with a result of $87.82 \%$ (very effective). The third indicator, incentive with the result of $88.94 \%$ (very effective). Finally, the indicator time with the percentage of approval is $89.56 \%$ (very effective). In addition, the qualitative data obtained also shows that the use of SPADA can support college student learning processes. 


\section{PENDAHULUAN}

Pada awal tahun 2020, World Health Organization (WHO) menyatakan bahwa pandemi Covid-19 sebagai status darurat kesehatan global (Public Health Emergency of International Concern). Hal ini menyebabkan pemerintah Indonesia memberlakukan peraturan untuk masyarakat agar melakukan pekerjaan dari rumah termasuk melaksanakan kegiatan belajar mengajar (Sanjaya, 2020). Peraturan tersebut dituangkan dalam Surat Edaran Nomor 36962/MPK.A/HK/2020 tentang Pembelajaran secara Daring dan Bekerja dari Rumah dalam Rangka Pencegahan Penyebaran Corona Virus Disease (Covid-19) (Kemendikbud, 2020). Dengan adanya peraturan tersebut, maka seluruh lembaga Pendidikan yang ada di Indonesia melaksanakan proses pembelajaran secara daring.

Pembelajaran daring merupakan proses pembelajaran yang didukung oleh suatu jaringan komputer lain dengan menggunakan media pembelajaran e-learning (Pratiwi, 2020). E-Learning adalah suatu pembelajaran yang menggunakan teknologi informasi dan komunikasi untuk mentransformasikan suatu proses pembelajaran antara dosen dengan mahasiswa. Tujuan utamanya yaitu untuk meningkatkan efisiensi dan efektivitas, transparansi, serta akuntabilitas pembelajaran (Pujiastutik, 2019). Pada saat pelaksanaan pembelajaran daring diperlukan adanya dukungan perangkat-perangkat mobile seperti smartphone, tablet, komputer maupun laptop.
Perangkat-perangkat tersebut digunakan untuk mengakses aplikasi $e$-learning serta mengakses informasi tentang materi pembelajaran dan hal lainnya. Penggunaan perangkat-perangkat tersebut dapat dilakukan kapan saja dan dimana saja. Teknologi mobile memiliki kontribusi yang sangat besar dalam dunia pendidikan. Berbagai macam media yang digunakan untuk mendukung kegiatan belajar mengajar secara daring, contohnya adalah menggunakan kelaskelas virtual seperti Google Classroom, Edmodo, Schoology, Moodle, Quipper School, Dokeos, dan $\operatorname{dot} L R N$, termasuk aplikasi pesan instan seperti WhatsApp. Pembelajaran daring bahkan dapat dilakukan dengan menggunakan sosial media seperti Facebook dan Instagram (Efendi, 2017; Firman \& Rahman, 2020). Pembelajaran daring juga dapat dilakukan dengan menggunakan video conference, contohnya adalah Google Meeting, Discord, Zoom, dan sebagainya.

Pada poses pembelajaran e-learning terjadi komunikasi dan interaksi mahasiswa dengan dosen dan mahasiswa dengan mahasiswa lainnya. Saat pembelajaran e-learning berlangsung, dosen tidak hanya mengunggah materi mata kuliah saja kepada mahasiswa, tetapi dosen juga melakukan evaluasi, menjalin komunikasi dengan membuka diskusi, dan mengelola aspek-aspek pembelajaran lainnya (Jamal, 2020). E-Learning digunakan untuk memfasilitasi setiap aktivitas pembelajaran maupun pelatihan saat proses belajar mengajar berlangsung baik secara formal maupun informal. Dosen dan mahasiswa mempunyai 
peran masing-masing dalam penerapan $e$ learning. Dosen mempunyai peran sebagai fasilitator dan pembimbing saat kegiatan belajar mengajar sedangkan mahasiswa mempunyai peran sebagai pembelajar mandiri (independent learners), pemecah masalah (problem solvers) dan konstruktor pengetahuan (Pratiwi, 2020).

STMIK Primakara telah mengembangkan platform pembelajaran daring yaitu SPADA (STMIK Primakara Online Learning System). Tujuan adanya SPADA adalah untuk membantu proses perkuliahan selama Covid19. Platform ini berbasis Moodle. Moodle (Modulator Object Oriented Dynamic Learning Environment) yang berarti pengajar dan peserta didik melakukan suatu aktivitas pembelajaran saat kegiatan online (Wicaksana, 2020). SPADA dapat diakses melalui spada.primakara.ac.id. Penggunaan SPADA mulai diberlakukan untuk seluruh pelaksanaan kegiatan perkuliahan daring Semester Ganjil Tahun Akademik 2020/2021. Dalam proses pengimplementasian SPADA mahasiswa melakukan proses belajar secara sinkron. Dimana pembelajaran secara sinkron merupakan proses pembelajaran secara langsung pada waktu yang sama serta dapat dilakukan walaupun terpisah oleh jarak dengan perantara alat komunikasi daring (Astawa \& Utami, 2020). Proses belajar secara sinkron di SPADA dilakukan dengan live chatting yaitu melalui diskusi. Mengunduh materi dan mengirim tugas mata kuliah juga dapat dilakukan di SPADA.

Berdasarkan hasil observasi yang dilakukan kepada bagian akademik STMIK
Primakara ditemukan bahwa pada bulan April 2020 selama belajar daring beban tugas mahasiswa dirasakan berlebihan, sulit dalam menangkap materi, jadwal perkuliahan yang tidak sesuai, serta komunikasi antara dosen dan mahasiswa perlu ditingkatkan lagi. Maka dari itu, dengan adanya SPADA diharapkan efektivitas belajar mahasiswa STMIK Primakara dapat menjadi semakin lebih baik. Dimana efektivitas pembelajaran adalah salah satu standar mutu pada pendidikan serta sebagai ukuran keberhasilan guna untuk mencapai tujuan yang didapat dari proses belajar mengajar. Syarat utama keefektifan pembelajaran adalah presentasi waktu belajar mahasiswa, sikap mahasiswa, ketepatan materi yang diajarkan dengan kemampuan mahasiswa, dan menjadikan suasana belajar menjadi akrab (Abidin et al., 2020).

Efektivitas pembelajaran sangatlah penting dalam proses pembelajaran mahasiswa dikarenakan efektivitas menunjukkan keberhasilan dari segi tercapai atau tidaknya sasaran yang telah ditetapkan. Jika hasil kegiatan semakin mendekati sasaran, artinya semakin tinggi efektivitasnya. Untuk mencapai tingkat efektivitas yang optimal, salah satu upaya yang perlu dilakukan adalah membuat kegiatan pembelajaran menjadi menarik sehingga dapat menimbulkan motivasi belajar mahasiswa serta perhatian mahasiswa menjadi terpusat terhadap topik materi mata kuliah yang dibahas dalam aktivitas pembelajaran (Badriyah, 2015). Aktivitas belajar mahasiswa merupakan suatu proses komunikasi atau interaksi yang dilakukan antara mahasiswa dan dosen, sehingga dapat menghasilkan suatu 
perubahan akademik, sikap, tingkah laku, keterampilan dan kedisiplinan mahasiswa untuk bertanya maupun menjawab. Semakin baik aktivitas belajar mahasiswa maka akan semakin efektif dan efisien proses belajar mengajar berlangsung. Sehingga penelitian ini, peneliti menggunakan indikator efektivitas pembelajaran menurut Slavin (1984; 1987a; 1994) (Slavin, 1995).

Menurut Slavin terdapat 4 (empat) indikator untuk mengukur efektivitas pembelajaran mahasiswa, yaitu quality of instruction (kualitas pembelajaran), appropriate levels of instruction (kesesuaian tingkat pembelajaran), incentive (insentif), dan time (waktu). Quality of Instruction (kualitas pembelajaran) merupakan sejauh mana penyajian informasi yang diajarkan oleh dosen sehingga mahasiswa dapat dengan mudah mempelajari materi tersebut. Appropriate Levels of Instruction (kesesuaian tingkat pembelajaran) merupakan sejauh mana kesiapan mahasiswa saat mempelajari materi pembelajaran baru. Incentive (insentif) merupakan sejauh mana mahasiswa dapat termotivasi dalam proses pembelajaran, seperti mengerjakan tugas-tugas serta mempelajari materi yang disajikan. Semakin besar motivasi yang diberikan, maka semakin besar juga keaktifan mahasiswa. Dengan demikian pembelajaran akan efektif. Time (waktu) merupakan sejauh mana waktu yang dibutuhkan untuk menyelesaikan kegiatan pembelajaran. Pembelajaran akan efektif jika mahasiswa dapat menyelesaikan pembelajaran sesuai dengan waktu yang telah ditentukan (Alfiyatin et al., 2020). Sehingga dapat disimpulkan bahwa penelitian ini bertujuan untuk mengetahui pengaruh e-learning menggunakan SPADA terhadap efektivitas belajar mahasiswa STMIK Primakara.

\section{METODE PENELITIAN}

Metode yang digunakan dalam penelitian ini yaitu mixed methods (penelitian kombinasi) kuantitatif dan kualitatif. Metode mixed methods merupakan suatu penelitian yang menggabungkan metode kuantitatif dengan metode kualitatif secara bersamaan dalam suatu penelitian, agar data yang didapat lebih valid, reliabel, dan obyektif. Hal tersebut dikarenakan data yang tidak dapat divalidasi menggunakan metode kuantitatif akan divalidasi dengan menggunakan metode kualitatif atau sebaliknya (Kurniasari et al., 2020). Metode penelitian ini menggunakan convergence model yaitu data kuantitatif dan data kualitatif yang dikumpulkan secara bersamaan, kemudian kedua data tersebut dianalisis dan digabungkan. Setelah itu, peneliti menginterpretasikan hasil dari penelitian tersebut (Sanjaya, 2015).

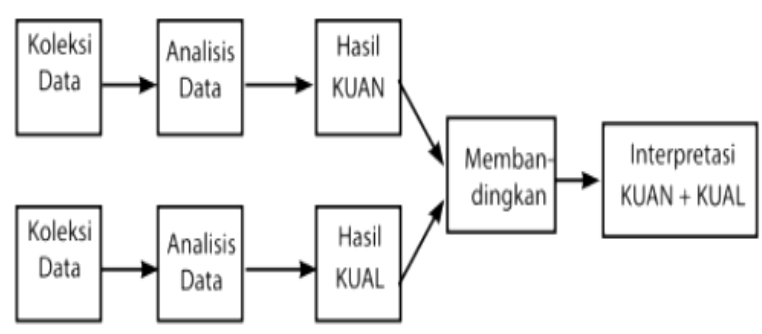

Gambar 1. Convergence Model

Teknik pengumpulan data pada penelitian ini, yaitu observasi, kuesioner tertutup, kuesioner terbuka, dan studi literatur. Observasi dilakukan dengan tujuan untuk mengamati hal- 
hal yang terjadi sebelum dilakukannya penelitian. Selanjutnya, kuesioner merupakan suatu teknik pengumpulan data yang digunakan untuk mendapatkan informasi dari responden yang berupa beberapa pertanyaan yang telah dibuat oleh peneliti. Pada penelitian ini, peneliti menggunakan kuesioner tertutup dan kuesioner terbuka. Dimana kuesioner tersebut diberikan kepada mahasiswa aktif STMIK Primakara semester 2, semester 4, dan semester 6 . Kuesioner tertutup menghasilkan data kuantitatif sedangkan kuesioner terbuka menghasilkan data kualitatif. Kuesioner dibuat berdasarkan komponen dari teori Slavin. Berikut ini merupakan rubrik kuesioner yang digunakan pada penelitian ini

Tabel 1. Rubrik Kuesioner

\begin{tabular}{|c|c|c|c|c|c|}
\hline \multirow[t]{2}{*}{ No } & \multirow[t]{2}{*}{ Aspek } & \multicolumn{2}{|c|}{ Kuesioner } & \multirow[t]{2}{*}{ Objektif } & \multirow{2}{*}{$\begin{array}{l}\text { Total } \\
\text { Item }\end{array}$} \\
\hline & & Tertutup & Terbuka & & \\
\hline 1. & $\begin{array}{l}\text { Quality of } \\
\text { Instruction }\end{array}$ & $1,2,3,4,5$ & 6 & $\begin{array}{l}\text { Untuk dapat mengetahui apakah } \\
\text { mahasiswa dapat dengan mudah } \\
\text { mempelajari materi pembelajaran. }\end{array}$ & 6 \\
\hline 2. & $\begin{array}{l}\text { Appropriate Levels } \\
\text { of Instruction }\end{array}$ & $7,8,9,10,11$ & 12 & $\begin{array}{l}\text { Untuk dapat mengetahui apakah } \\
\text { mahasiswa sudah siap } \\
\text { mempelajari suatu materi } \\
\text { pembelajaran baru. }\end{array}$ & 6 \\
\hline 3. & Incentive & $13,14,15,16,17$ & 18 & $\begin{array}{l}\text { Untuk dapat mengetahui apakah } \\
\text { mahasiswa dapat termotivasi } \\
\text { dalam mengerjakan tugas-tugas } \\
\text { serta mempelajari materi } \\
\text { pembelajaran. }\end{array}$ & 6 \\
\hline 4. & Time & $19,20,21,22,23,24$ & 25 & $\begin{array}{l}\text { Untuk dapat mengetahui apakah } \\
\text { mahasiswa dapat diberikan waktu } \\
\text { yang cukup dalam mempelajari } \\
\text { materi yang sedang diajarkan }\end{array}$ & 7 \\
\hline
\end{tabular}

Studi literatur merupakan suatu teknik pengumpulan data yang dilakukan oleh peneliti dengan mengumpulkan data dari penelitianpenelitian sebelumnya yang relevan serta membahas topik yang sama. Contohnya, jurnal penelitian, laporan penelitian, buku, dan lainlain. Pada penelitian ini, peneliti mencari studi literatur yang membahas topik mengenai pendidikan terutama e-learning, penelitian yang menggunakan mixed methods, dan indikator efektivitas pembelajaran terutama dari teori Slavin yang artikelnya berasal dari The Educational Forum. Dengan adanya studi literatur pada penelitian ini, dapat memperkuat hasil dari penelitian.

Adapun populasi dari penelitian ini adalah mahasiswa aktif STMIK Primakara yang berjumlah 584 mahasiswa. Pengambilan sampel pada penelitian ini adalah menggunakan probability sampling yaitu simple random sampling. Dimana simple random sampling merupakan sebuah teknik pengambilan sampel yang dilakukan secara acak (random) dan setiap unit mempunyai kesempatan yang sama dalam menjadi sampel penelitian (Sumargo, 2020). Untuk menghitung sampel penelitian, 
peneliti menggunakan rumus Slovin (Ismail, 2018), sebagai berikut:

$$
\mathrm{n}=\mathrm{N} / 1+\mathrm{Ne}^{2}
$$

Keterangan:

$\mathrm{n}$ = jumlah sampel

$\mathrm{N}$ = jumlah populasi

$\mathrm{e}=$ batas kesalahan (error tolerance)

1 = bilangan konstan

Dari hasil perhitungan sampel dengan menggunakan tingkat kesalahan 10\%, maka diperoleh jumlah sampel yang digunakan pada penelitian ini adalah 85 responden.

Pengujian kuesioner tertutup dilakukan uji validitas dan uji reliabilitas. Pengujian dilakukan dengan menggunakan IBM SPSS Statistics 25. Instrumen dikatakan valid, jika r hitung $\geq \mathrm{r}$ tabel sedangkan instrumen dikatakan tidak valid, jika $r$ hitung $<r$ tabel. Instrumen dikatakan reliabel jika, nilai Alpha Cronbach> 0,7 (Riyanto \& Hatmawan, 2020). Setelah melakukan pengujian, instrumen pada penelitian ini dikatakan valid dan reliabel sehingga layak untuk dijadikan instrumen penelitian.

\section{Perhitungan kuesioner tertutup} menggunakan skala Likert dengan ketentuan skornya yaitu sangat setuju $=4$, setuju $=3$, tidak setuju $=2$, dan sangat tidak setuju $=1$. Skor maksimum adalah 4 dan skor minimum adalah 1 (25\% dari skor maksimum). Untuk mengetahui persentase persetujuan dari kuesioner ini, peneliti menggunakan rumus (Sugiono, 2012), sebagai berikut:

$$
p=f / n \times 100 \%
$$

Keterangan:

$\mathrm{p} \quad=$ persentase

$\mathrm{f} \quad=$ frekuensi setiap jawaban kuesioner

$\mathrm{n} \quad=$ jumlah skor ideal

100 = bilangan tetap

\section{HASIL DAN PEMBAHASAN}

Berikut ini merupakan pengaruh penggunaan SPADA terhadap efektivitas belajar mahasiswa STMIK Primakara dengan menggunakan indikator quality of instruction, appropriate levels of instruction, incentive, dan time.

Tabel 2. Hasil Perhitungan Dengan Indikator

\begin{tabular}{|c|c|c|}
\hline $\begin{array}{c}\text { Skala } \\
\text { Jawaban }\end{array}$ & $\begin{array}{c}\text { Skala Jawaban } \times \text { Nilai } \\
\text { Skala }\end{array}$ & Hasil \\
\hline SS & $231 \times 4$ & 924 \\
\hline $\mathrm{S}$ & $156 \times$ & 468 \\
\hline TS & $38 \times 2$ & 76 \\
\hline STS & $0 \times 1$ & 0 \\
\hline \multirow{2}{*}{\multicolumn{2}{|c|}{$\begin{array}{c}\text { Total } \\
\text { Jumlah Skor Ideal }\end{array}$}} & 1468 \\
\hline & & 1700 \\
\hline
\end{tabular}
Quality of Instruction

Pengaruh penggunaan SPADA terhadap efektivitas belajar mahasiswa STMIK Primakara dengan indikator quality of instruction didapatkan persentase persetujuannya adalah $86,35 \%$. Hal tersebut mengindikasikan bahwa mahasiswa dapat dengan mudah mempelajari materi pembelajaran di SPADA. Beberapa tanggapan dari responden juga membenarkan pernyataan tersebut, yaitu tanggapan dari responden dengan kode S01/M menyatakan bahwa, "Cukup mudah untuk dipahami, apalagi jika 
berupa video materi pembelajarannya". Tanggapan dari responden dengan kode S32/F menyatakan bahwa, "Iya, terutama dalam mata kuliah aljabar linier, statistika dan probabilitas". Tanggapan dari responden dengan kode S38/F menyatakan bahwa, "Iya, karena di SPADA ada materi berupa video/teks yang bisa memudahkan dalam belajar". Hal ini juga didukung oleh penelitian yang dilakukan (Monica \& Fitriawati, 2020) menyatakan bahwa pembelajaran secara online mendapat tanggapan yang baik dikarenakan pembelajarannya lebih fleksibel dalam menggunakannya serta menjadikan mahasiswa lebih mandiri dalam mempelajari materi yang telah diajarkan.

Tabel 3. Hasil Perhitungan Dengan Indikator Appropriate Levels of Instruction

\begin{tabular}{|c|c|c|}
\hline $\begin{array}{c}\text { Skala } \\
\text { Jawaban }\end{array}$ & $\begin{array}{c}\text { Skala Jawaban } \times \text { Nilai } \\
\text { Skala }\end{array}$ & Hasil \\
\hline SS & $244 \times 4$ & 976 \\
\hline $\mathrm{S}$ & $156 \times 3$ & 468 \\
\hline TS & $24 \times 2$ & 48 \\
\hline STS & $1 \times 1$ & 1 \\
\hline \multicolumn{2}{|c|}{$\begin{array}{c}\text { Total } \\
\text { Jumlah Skor Ideal }\end{array}$} & 1493 \\
\hline
\end{tabular}

Pengaruh penggunaan SPADA terhadap efektivitas belajar mahasiswa STMIK Primakara dengan indikator appropriate levels of instruction didapatkan persentase persetujuannya adalah $87,82 \%$. Hal tersebut mengindikasikan bahwa mahasiswa sudah siap mempelajari suatu materi pembelajaran baru di SPADA. Beberapa tanggapan dari responden juga membenarkan pernyataan tersebut, yaitu tanggapan dari responden dengan kode S22/M menyatakan bahwa, "Sudah, karena SPADA memfasilitasi dengan bagus". Tanggapan dari responden dengan kode S33/F menyatakan bahwa, "Tentu siap, selama masih bisa mengerti”. Tanggapan dari responden dengan kode S38/F menyatakan bahwa, "Siap, karena di SPADA materi baru sudah ada modul/videonya. Hal ini juga didukung oleh penelitian yang dilakukan (Sabran \& Sabara, 2019) menyatakan bahwa aspek perencanaan pembelajaran menggunakan media e-learning termasuk cukup efektif, dikarenakan kesiapan mahasiswa dalam meningkatkan pembelajaran e-learning.

Tabel 4. Hasil Perhitungan Dengan Indikator Incentive

\begin{tabular}{|c|c|c|}
\hline $\begin{array}{c}\text { Skala } \\
\text { Jawaban }\end{array}$ & $\begin{array}{c}\text { Skala Jawaban } \times \text { Nilai } \\
\text { Skala }\end{array}$ & Hasil \\
\hline SS & $253 \times 4$ & 1012 \\
\hline $\mathrm{S}$ & $157 \times 3$ & 471 \\
\hline TS & $14 \times 2$ & 28 \\
\hline STS & $1 \times 1$ & 1 \\
\hline \multirow{2}{*}{\multicolumn{2}{|c|}{$\begin{array}{c}\text { Total } \\
\text { Jumlah Skor Ideal }\end{array}$}} & 1512 \\
\hline & & 1700 \\
\hline
\end{tabular}

Pengaruh penggunaan SPADA terhadap efektivitas belajar mahasiswa STMIK Primakara dengan indikator incentive didapatkan persentase persetujuannya adalah $88,94 \%$. Hal tersebut mengindikasikan bahwa mahasiswa dapat termotivasi untuk mengerjakan tugas-tugas serta mempelajari materi pembelajaran. Beberapa tanggapan dari responden juga membenarkan pernyataan tersebut, yaitu tanggapan dari responden dengan kode S21/M menyatakan bahwa, "Iya, termotivasi apalagi ada diskusi”. Tanggapan dari responden dengan kode S37/F menyatakan bahwa, "Termotivasi, karena mendapatkan informasi baru". Tanggapan dari responden dengan kode S42/F menyatakan bahwa, 
"Termotivasi, supaya bisa mendapatkan nilai akhir yang baik". Hal ini juga didukung oleh penelitian yang dilakukan (Sadikin \& Hamidah, 2020) menyatakan bahwa pembelajaran daring dapat membuat mahasiswa belajar secara mandiri dan membuat motivasi mahasiswa meningkat.

Tabel 5. Hasil Perhitungan Dengan Indikator Time

\begin{tabular}{|c|c|c|}
\hline $\begin{array}{c}\text { Skala } \\
\text { Jawaban }\end{array}$ & $\begin{array}{c}\text { Skala Jawaban } \times \text { Nilai } \\
\text { Skala }\end{array}$ & Hasil \\
\hline SS & $317 \times 4$ & 1268 \\
\hline $\mathrm{S}$ & $174 \times 3$ & 522 \\
\hline TS & $18 \times 2$ & 36 \\
\hline STS & $1 \times 1$ & 1 \\
\hline \multirow{2}{*}{\multicolumn{2}{|c|}{$\begin{array}{c}\text { Total } \\
\text { Jumlah Skor Ideal }\end{array}$}} & 1827 \\
\hline & & 2040 \\
\hline
\end{tabular}

Pengaruh penggunaan SPADA terhadap efektivitas belajar mahasiswa STMIK Primakara dengan indikator time didapatkan persentase persetujuannya adalah $89,56 \%$. Hal tersebut mengindikasikan bahwa mahasiswa dapat diberikan waktu yang cukup dalam mempelajari materi yang sedang diajarkan. Beberapa tanggapan dari responden juga membenarkan pernyataan tersebut, yaitu tanggapan dari responden dengan kode S02/M menyatakan bahwa, "Iya, cukup karena online". Tanggapan dari responden dengan kode S12/F menyatakan bahwa, "Cukup, karena di SPADA tersedia video penjelasannya yang baru saja diajarkan makanya dapat dipelajari lagi". Tanggapan dari responden dengan kode S34/F menyatakan bahwa, "Waktu yang diberikan sudah cukup". Hal ini juga didukung oleh penelitian yang dilakukan (Sadikin \& Hamidah, 2020) menyatakan bahwa pembelajaran daring efektif dikarenakan saat kelas virtual dapat diakses dimana saja dan kapan saja.

\section{SIMPULAN}

Berdasarkan dari hasil penelitian pengaruh e-learning menggunakan SPADA terhadap efektivitas belajar mahasiswa STMIK Primakara dengan menggunakan indikator quality of instruction, appropriate levels of instruction, incentive, dan time, maka dapat disimpulkan bahwa keempat indikator tersebut dapat membuktikan bahwa e-learning menggunakan SPADA dapat berpengaruh positif dan signifikan terhadap efektivitas belajar mahasiswa STMIK Primakara.

Mahasiswa hendaknya memiliki komitmen dalam meningkatkan efektivitas pembelajarannya serta mempertahankan keaktifannya selama proses belajar mengajar berlangsung. Dalam pemberian materi oleh dosen dibuat semenarik mungkin agar mahasiswa termotivasi dalam mempelajari materi pelajaran, misalnya dengan memberikan materi berupa video, melakukan diskusi dengan menciptakan suasana yang ceria, dan mengakhiri perkuliahan dengan kalimatkalimat yang memotivasi. Diharapkan dalam penggunaan SPADA, perlu adanya pengoptimalan supaya tetap stabil.

\section{DAFTAR RUJUKAN}

Abidin, Z., Hudaya, A., \& Anjani, D. (2020). Efektivitas Pembelajaran Jarak Jauh Pada Masa Pandemi Covid-19. Research and Development Journal of Education, 131-146. https://doi.org/http://dx.doi.org/10.309 98/rdje.v1i1.7659 
Alfiyatin, Y., Heriyanto, \& Nabila. (2020). Efektivitas Pembelajaran Daring Dalam Pandangan Siswa MI ALFALAH Dakiring-Bangkalan. AlIbrah, 5(2), 1-22.

Astawa, N. L. P. N. S. P., \& Utami, N. W. (2020). Pelatihan Pembuatan Buku Cerita Digital Sederhana Sebagai Bahan Ajar dalam Kondisi New Normal. Jurnal Karya Abdi, 4(1), 143147.

Badriyah. (2015). Efektifitas Proses Pembelajaran Dengan Pemanfaatan Media Pembelajaran. Jurnal Lentera Komunikasi, 1(1), 21-36.

Efendi, A. (2017). E-Learning Berbasis Schoology Dan Edmodo: Ditinjau Dari Motivasi Dan Hasil Belajar Siswa Smk. Elinvo (Electronics, Informatics, and Vocational Education), 2(1), 49-58. https://doi.org/10.21831/elinvo.v2i1.1 6416

Firman, \& Rahman, S. R. (2020). Pembelajaran Online di Tengah Pandemi Covid-19. Indonesian Journal of Educational Science (IJES), 2(2), 81-89. https://doi.org/10.31605/ijes.v2i2.659

Ismail, F. (2018). Statistika: Untuk Penelitian Pendidikan dan Ilmu-Ilmu Sosial. Kencana.

Jamal, S. (2020). Analisis Kesiapan Pembelajaran E-Learning Saat Pandemi Covid-19 Di Smk Negeri 1 Tambelangan. Jurnal Nalar Pendidikan, 8(1), 16-22. https://doi.org/10.26858/jnp.v8i1.1356 1

Kemendikbud. (2020). Surat Edaran Menteri Pendidikan dan Kebudayaan Republik Indonesia Nomor 36962/MPK.A/HK/2020. Mendikbud RI.

Kurniasari, A., Pribowo, F. S. P., \& Putra, D. A. (2020). Analisis Efektivitas Pelaksanaan Belajar Dari Rumah (BDR) Selama Pandemi Covid-19. Jurnal Review Pendidikan Dasar:
Jurnal Kajian Pendidikan dan Hasil Penelitian, 6(3), 1-8.

Monica, J., \& Fitriawati, D. (2020). Efektivitas Penggunaan Aplikasi Zoom Sebagai Media Pembelajaran Online Pada Mahasiswa Saat Pandemi Covid-19. Jurnal Communio: Jurnal Jurusan Ilmu Komunikasi, 9(2), 1630-1640. https://doi.org/10.35508/jikom.v9i2.24 16

Pratiwi, E. W. (2020). Dampak Covid-19 Terhadap Kegiatan Pembelajaran Online Di Perguruan Tinggi Kristen Di Indonesia. Perspektif Ilmu Pendidikan, 34(1), 1-8. https://doi.org/10.21009/pip.341.1

Pujiastutik, H. (2019). Efektivitas Penggunaan Media Pembelajaran E-Learning Berbasis Web Pada Mata Kuliah Belajar Pembelajaran I Terhadap Hasil Belajar Mahasiswa. Jurnal Teladan, 4(1), 26-36.

Riyanto, S., \& Hatmawan, A. A. (2020). Metode Riset Penelitian Kuantitatif Penelitian di Bidang Manajemen, Teknik, Pendidikan dan Eksperimen. DEEPUBLISH.

Sabran, \& Sabara, E. (2019). Keefektifan Google Classroom sebagai Media Pembelajaran. PROSIDING SEMINAR NASIONAL LEMBAGA PENELITIAN UNIVERSITAS NEGERI MAKASSAR, 122-125.

https://webcache.googleusercontent.co $\mathrm{m} / \mathrm{search}$ ? $\mathrm{q}=$ cache:SS_jKM_r2TAJ:htt ps://ojs.unm.ac.id/semnaslemlit/article /download/8256/4767+\&cd=2\&hl=id $\& \mathrm{ct}=\mathrm{clnk} \& \mathrm{gl}=\mathrm{id}$

Sadikin, A., \& Hamidah, A. (2020). Pembelajaran Daring di Tengah Wabah Covid-19. Biodik, 6(2), 109-119. https://doi.org/10.22437/bio.v6i2.9759

Sanjaya. (2020). 21 Refleksi Pembelajaran Daring di Masa Darurat. SCU Knowledge Media.

Sanjaya, W. (2015). Penelitian Pendidikan: Jenis, Metode, dan Prosedur. Kencana. 
Slavin, R. E. (1995). A Model of Effective Instruction. Educational Forum, 59(2), 166-176.

https://doi.org/10.1080/001317295093 36383

Sugiono. (2012). Metode Penelitian Kuantitatif, Kualitatif dan $R \& D$. Alfabeta.

Sumargo, B. (2020). Teknik Sampling. UNJ PRESS.

Wicaksana, E. (2020). Efektifitas Pembelajaran Menggunakan Moodle Terhadap Motivasi Dan Minat Bakat Peserta Didik Di Tengah Pandemi Covid -19. EduTeach: Jurnal Edukasi dan Teknologi Pembelajaran, 1(2), 117124.

https://doi.org/10.37859/eduteach.v1i2 .1937 